\title{
The effect of work-family conflict and flexible work arrangement on turnover intention: do female and male employees differ?
}

\author{
Nastyalita Gunaprasida', Amin Wibowo ${ }^{2}$ \\ ${ }^{1}$ Alumna of Faculty of Economics and Business, Universitas Gadjah Mada, Yogyakarta, Indonesia \\ ${ }^{2}$ Faculty of Economics and Business, Universitas Gadjah Mada, Yogyakarta, Indonesia \\ *Corresponding author: aminwibowo@ugm.ac.id
}

\begin{abstract}
The purpose of this paper is to examine the effect of work-family conflict, and flexible work arrangements as moderating variable on the intention to leave for female and male employees. The population in this study is hotel employees in Yogyakarta. Hospitality industry is categorized as industry with high employee turnover rate, while hotel management must retain the best employees. Using survey data from 167 hotel employees in Yogyakarta, simple and moderated regression analysis show that overall, work-family conflict positively influenced intention to leave, while flexible work arrangement do not significantly moderate the relationship of that variables. However, when the sample is split between male and female employees it shows different result, as for the female employees a flexible work arrangement moderates the relationship between work-family conflict and turnover intention, while for male workers the moderating effect is not significant. This research shows that gender takes role as female employees demand more flexible work arrangements when confronted with negative work experience than male employees. It is suggested for future research that considering sample population from other industries such as banking industry and hospital may make research more generalizable and adding interview method may give more insight about the topic of the research.
\end{abstract}

Keywords: Turnover intention, work-family conflict, flexible work arrangement

\begin{abstract}
Abstrak
Tujuan dari makalah ini adalah untuk menguji pengaruh konflik kerja-keluarga, dan pengaturan kerja yang fleksibel sebagai variabel moderasi pada niat untuk keluar dari pekerjaan untuk karyawan wanita dan pria. Populasi dalam penelitian ini adalah karyawan hotel di Yogyakarta. Industri perhotelan dikategorikan sebagai industri dengan tingkat perputaran karyawan yang tinggi, sedangkan manajemen hotel harus mempertahankan karyawan terbaik. Menggunakan data survei dari 167 karyawan hotel di Yogyakarta, analisis regresi sederhana dan moderasi menunjukkan bahwa secara keseluruhan, konflik pekerjaan-keluarga secara positif memengaruhi niat untuk keluar dari pekerjaan, sementara pengaturan kerja yang fleksibel tidak secara signifikan memoderasi pengaruh di antara keduanya. Namun, ketika sampel dipecah antara karyawan pria dan wanita, penelitian ini menunjukkan hasil yang berbeda, karena bagi karyawan wanita, pengaturan kerja yang fleksibel memoderasi hubungan antara konflik kerja-keluarga dan intensi untuk keluar dari pekerjaan, sedangkan untuk pekerja pria efek moderasi tidak signifikan. Penelitian ini menunjukkan bahwa gender berperan penting, karyawan wanita menuntut pengaturan kerja yang lebih fleksibel ketika dihadapkan dengan pengalaman kerja negatif daripada karyawan pria. Disarankan untuk penelitian masa depan untuk mempertimbangkan sampel dari industri lain seperti industri perbankan dan rumah sakit agar penelitian lebih digeneralisasikan, dan melengkapi dengan metode wawancara memungkinkan untuk mendapatkan gambaran yang lebih dalam mengenai topik riset ini.
\end{abstract}

Kata kunci: Intensi keluar, konflik pekerjaan-keluarga, pengaturan kerja fleksibel

JEL Code: M19 DOI: 10.20885/jsb.vol23.iss1.art3

Introduction

Employee turnover has become a great challenge for hospitality industry to retain its best personnel (Tromp \& Blomme, 2014). For example, in the US in 2013, more than 25 million U.S. employees 
The effect of work-family conflict and flexible work arrangement on turnover intention: do female and male employees differ?

voluntarily terminated their employment, with costs to replace an employee averaging from $25 \%$ to as much as $500 \%$ of the terminated employee's annual salary (Bryant \& Allen, 2013). Recent report indicated that employee turnover rate was about $48 \%$ per year in the leisure and hospitality industries from April 2015 to April 2016 (U.S. Department of Labor, 2016). As comparison, based on Indonesian's Statistics Organization (BPS), in 2014 Indonesian hospitality industry's turnover level was at $21.43 \%$, it decreased a little into $21.34 \%$ in 2015 and rose up to $24 \%$ in 2016 (BPS, 2017). Comparing to hospitality industry in global, these numbers are considered high from the average number of 20.7\% in 2016 (CompData Surveys, 2017).

Hospitality industry could be categorized as one of industries which have a high level of stress because of working conditions (Mansour \& Tremblay, 2016). When a person experiences stressful events at work, he or she tends to be less satisfied with his or her job, which in turn results in frustration and make it difficult to balance both work and family life (Haar et al., 2012). These negative emotions could affect employee attitude toward work and employee decision to stay in the organizations.

The hospitality industry is often characterized as industry which has long working days and hours, a high need for schedule coordination at irregular hours (Blomme et al., 2010b). Rigid work schedule makes employee hard to distribute his/her resources between work and family. Accordingly, strains will occur because environmental demands or constraints perceived by employee are exceeding his or her resources or capacities. Job stress caused by role conflict can lead to job disengagement which resulting in employee to quit his/her job (Afsar \& Rehman, 2017).

Abundant research has found that work-family conflict has negative impact to work outcomes, such as job satisfaction, job stress, organizational commitment and intention to leave (Mansour \& Tremblay, 2016; Tromp \& Blomme, 2014 Porter \& Ayman, 2013). However, very limited studies had focused on the impact of working-family conflict on different gender (Hoque, 1999; Bloome et.al, 2010a among many others), and to make matter worse such studies mainly performed in western and developed countries. As part of growing industry in the global context, hospitality industries everywhere were the host of many visitors from developed and developing countries who demand better services from employees for what they have paid for. For that reason, it was very surprising to see the shortage of the study in this area.

Work-family conflict is a form of inter-role conflict in which the role pressures from the work and family domains are mutually incompatible (Greenhaus \& Beutell, 1985). Work-family conflict happens when there is trade-off between individual's role as an employee and family member (Afsar \& Rehman, 2017). As industrialization brought significant economic and social structure changes, the traditional collectivist culture in Asia including Indonesia is shifting (Mortazavi et al., 2009). Traditionally, men focus more on their work, while women are expected to pay more attention to family, but above changes contribute to the increasing number of working women. A cultural tradition in developing countries positioned the women to raise the children, be a good wife, and do more on home-related tasks, but new trend indicated the expansion of the female role to include economic provision to family (OECD, 2011). Work-family conflict issue is becoming more important due to the increase in the number of women and dual-earner partners entering the labor force. In order to accomplish the balance in work and family life, individual must make sacrifices as of trade-off cannot be avoided (Haar et al., 2012). Especially to women in developing countries in this hospitality industries, balancing work and family life is considered more problematic as they must perform dual functions - as a wife and mother, and as professional employees.

To lessen the effect of work-family conflict, flexible work arrangement can be applied according to some researchers (Allen et al., 2013; De Sivatte \& Guadamillas, 2013). Flexible work arrangement can help employee to control and allocate his or her time, attention, and energy effectively (Allen et al., 2013). Through flexible work arrangement, the border between work and family becoming thin so that employee can integrate work and family activities much better (Resmiatini, 2016). The availability of flexible work arrangement helps employees building positive 
work attitudes thus eliminating negative emotions toward work which result in employee staying in the company.

The impacts of work-family conflict on turnover intention has been proven by many researchers (Chen et al., 2018; Wang et al., 2017; Blomme et al., 2010b), yet the effect of flexible work arrangement to work-family conflict and turnover intention to different gender is still lacking evidence. Thus, the purpose of this study is to offers a new insight in which gender might take important roles in the utilization of flexible work arrangements.

\section{Literature Review}

\section{The Impact of Work-Family Conflict on Turnover Intention}

Emotional exhaustion caused by work-family conflict will increase the chance for employee to leave the organization (Blomme et al., 2010b; Frone, et al., 1997). The emotions felt in the workplace are felt at home which results in employee find it hard (1) to focus while doing work and (2) to change their behaviors and feeling between work domain and family domain within short period of time (Haar et al., 2012). Spillover theory explained by Staines (1980) defines that employee's attitude and behavior can change between work and home. As example, employee who is satisfied with his or her work life will likely be satisfied with his or her family life and vice versa. Hence, any changes in employee's attitude and behavior may be indicated as a sign whether he or she is experiencing workfamily conflict or not. If employee keeps showing negative behaviors towards work, there is a high chance for turnover intention to occur. Recent study does confirm that work-family conflict is positively related with turnover intentions (Wang et al., 2017; Chen et al., 2018). Therefore, it can be hypothesized as:

H1: Work-family conflict positively affects employee's turnover intention.

\section{Flexible Work Arrangement as Moderating Variable}

Work flexibility is considered as an important practice for organization to help employee organizing work and family demands (Allen et al., 2013; Suprapto, et al., 2018). Individuals who perceive more work flexibility than their colleagues are able to work longer hours before their workload negatively impact their work-life balance (Porter \& Ayman, 2013. Flexible work arrangement can delay the negative effects caused by overwhelming workload before it affects their work-life balance. Flexible work arrangements (FWAs) are strategies by which employees can better balance demands from multiple domains (Timms et al., 2015).

Swanberg et al., (2008) argued that flexible work arrangement has become an important variable since it is believed to have an impact toward job stress and work-family conflict. Flexible work arrangement helps employees to balance their role at work and home (Afsar \& Rehman, 2017; Masuda, et al., 2012). In addition, employees who utilize flexible work arrangement have the ability to organize activities outside workplace better than those who work statically (Grant et al., 2013; McNall, et al., 2010). Hence, employee's control over time, energy, and other resources may encourage positive attitude so that employee turnover intention can be reduced. Drawing from above reasons, it is expected that having flexible work arrangement in place may reduce the negative impact of work-family conflict to turnover intentions.

Through flexible work arrangement organizations, or hotel management precisely, attempt to reduce employee's pressures due to the increase in demands and responsibility between work and family life (de Sivatte \& Guadamillas, 2013). If flexible work arrangement offered by hotel management gives benefits to employees, they will likely to stay in the organizations as a token of appreciation. Therefore, it can be hypothesized as:

$\mathrm{H} 2$ : Flexible work-arrangement moderates the impact of work-family conflict on turnover intention. 
Having hypothesized the moderating role of flexible work-arrangement on the relationship of work-family conflict on turnover intention, this study acknowledged the limited evidence of research that differentiate the role of gender in the above relationship. The nurturing role of women, as caretakers of children and elders, as well as educator versus the breadwinner role of men in the social pattern was historically documented. But recent trend showed the increase in the number of women and dual-earner partners entering the labor force. More responsibility is requested by the family after females get married and have children (Chen et al., 2018; Duxbury and Higgins, 1991; Sharma, 2012). According Eagly and Karau (1991) the gender role theory explained why men and women tend to place different importance on work and family roles due to the stereotypes associated with the roles they occupy. Men tend to place more emphasis on their work roles than women, who may place more emphasis on their family roles. Eagly (1987) emphasized social conditioning that influence different genders' attitudes toward their social roles where women always view their family roles as equally or even more important than their work-related roles.

As consequences, it is expected that the men and women react differently the existence of flexible work arrangement. Example of flexible employment options that organisations can provide is family-specific and include on-site childcare facilities. Female employees who have family responsibility see this provision attractive, lessening the tense between family and work (Timms et al., 2015). The above review suggests that gender role theory can be used as a theoretical framework for explaining gender differences regarding the relationship between work-family conflict and turnover intentions among hotel employees.

H3: Flexible work arrangement moderates more the impact of work-family conflict on turnover intention on female employees than on male employees.

\section{Methods}

\section{Sample and Data Collection}

The hospitality industry is characterized by long working days, working long hours, low job security, a high need for coordination with others and shift work at irregular hours (Bloome et al., 2010a). The study was conducted in the hospitality industry in Yogyakarta - one of the most attractive tourist destinations in Indonesia. The sample population chosen was employees who: (1) have worked in a hotel at least 6 months (2) have married and have children and (3) are not living with parents and parent in-laws. Having these criteria, it is expected to better capture the psychological mechanisms the variables under investigation to influence the intention to quit among employees in hospitality industry. Questionnaire was distributed to employees with the help of HRD Managers in each hotel. The questionnaires were given to 200 employees of seven hotels in Yogyakarta, and 180 were returned but only 167 that is considered appropriate for further analysis.

\section{Measurement}

Work-family conflict is a form of inter-role conflict in which the responsibilities from the work and family domains are mutually incompatible thus negatively affect any responsibilities in other domain (Netemeyer et al., 1996). Work-family conflict were measured with the scales by Netemeyer, et al., (1996) consisting of 5 items. Examples of the items are "The demands of my work interfere with my home and family life" and "The amount of time my job takes up makes it difficult to fulfill family responsibilities".

Meanwhile, turnover intention is defined as an employee's plan for intention to quit the present job and look forward to finding another job in the near future (Purani \& Sahadev, 2007). Turnover intention were measured with the scales by Mobley et al. (1978) consisting of 3 items. Examples of the items are "I might looking for a new job next year" and "I often think to leave my present job". Both variables were measured using the five point Likert-type scale (from $1=$ strongly disagree to $5=$ strongly agree). 
Flexible work arrangement is defined as "employer provided benefits that permit employees some level of control over when and where they work outside of the standard workday" (Lambert et al., 2008). Flexible work arrangement were measured with the scales developed by de Sivatte and Guadamillas (2013) consisting of 8 items. Examples of the items are "flextime", "compressed work weeks" and "telework". This measurement were using the five point Likert-type scale (from $1=$ no one to $5=$ everyone).

\section{Results and Discussion}

\section{Data Analysis}

The results of descriptive analysis are presented in Table I consisting the mean, standard deviations and the correlation coefficient between the variables. The turnover intention variables positively correlate with work-family conflict $(r=0.507)$. Meanwhile the flexible work arrangement as moderating variable positively correlate with turnover intention at 0.326 .

Table 1. Descriptive analysis

\begin{tabular}{llcccccc}
\hline \multicolumn{1}{c}{ Variable } & Mean & SD & 1 & 2 & 3 & 4 & 5 \\
\hline 1. Turnover Intention & 2.27 & 0.75 & 1 & $0.19^{*}$ & $0.20^{* *}$ & $0.51^{* *}$ & $0.326^{* *}$ \\
2. Gender & 0.37 & 0.46 & & 1 & $0.22^{* *}$ & $0.22^{* *}$ & 0.14 \\
3. Job Type & 0.72 & 0.45 & & & 1 & $0.20^{*}$ & 0.13 \\
4. Work-Family Conflict & 2.41 & 0.71 & & & & 1 & $0.33^{* *}$ \\
5. Flexible Work Arrangement & 2.02 & 0.76 & & & & & 1 \\
Note: ${ }^{*}<0.05 ; *<0.01$ & & & & & & & \\
\hline
\end{tabular}

This study is using a simple linear regression to test hypothesis 1 and a moderated regression analysis to test hypotheses 2 and 3. Based on Table 2, it can be concluded that gender and job type as control variables significantly influence turnover intention $(p<0.05)$, shown in Model 1 . Model 2 shows that work-family conflict positively influence turnover intention $(\beta=0.474 ; p<0.05)$, thus hypothesis 1 is supported. Model 3 shows that flexible work arrangement significantly influences turnover intention $(\beta=0.169 ; p<0.05)$. Model 4 shows that moderating effect of flexible work arrangement on the effect of work-family conflict to turnover intention does not show a significant effect $(\beta=0.554 ; p>0.05)$, so hypothesis 2 is not supported.

Table 2. Hypotheses testing using flexible work arrangement as the moderating variable and turnover intention as the dependent variable

\begin{tabular}{lrrrr}
\hline Variable & Model 1 & Model 2 & Model 3 & Model 4 \\
\hline Job Type & $0.166^{*}$ & $0.091 \mathrm{k}$ & $0.081 \mathrm{k}$ & $0.073 \mathrm{k}$ \\
Gender & $0.156^{*}$ & $0.069 \mathrm{k}$ & $0.058 \mathrm{k}$ & $0.063 \mathrm{k}$ \\
Work-Family Conflict & & $0.474^{*}$ & $0.423^{*}$ & $0.712^{*}$ \\
Flexible Work Arrangement & & & $0.169 *$ & $0.550 \mathrm{k}$ \\
Flexible Work Arrangement-Moderating & & & & $0.554 \mathrm{k}$ \\
$R^{2}$ & $0.064 \mathrm{k}$ & $0.272 \mathrm{k}$ & $0.297 \mathrm{k}$ & $0.305 \mathrm{k}$ \\
$\Delta R^{2}$ & & $0.208 \mathrm{k}$ & $0.025 \mathrm{k}$ & $0.008 \mathrm{k}$ \\
F-value & $5.563^{*}$ & $20.296^{*}$ & $17.142^{*}$ & $14.112^{*}$ \\
Note: $* 0.05$ & & & & \\
\hline
\end{tabular}




\section{Hypothesis Testing by Splitting Sample on Gender}

As shown in Table 2, gender influences turnover intention significantly and thus work-family conflict and flexible work arrangement were regressed together which split the result into male employees and female employees, presented in Table 3 Table 4 respectively. Based on Table 3, Model 1 shows that work-family conflict positively influences turnover intention on male employees $(\beta=0.443 ; p<$ 0.05). Model 2 and Model 3 shows that flexible work arrangement and its moderating effect do not significantly influence turnover intention on male employees $(\beta=0.228 ; \beta=0.292 ; p>0.05)$.

Table 3. Hypotheses testing using flexible work arrangement as the moderating variable and turnover intention as the dependent variable on male employees

\begin{tabular}{lccc}
\hline Variable & Model 1 & Model 2 & Model 3 \\
\hline Work-Family Conflict & $0.443^{*}$ & $0.394^{*}$ & 0.241 \\
Flexible Work Arrangement & & 0.228 & 0.013 \\
Flexible Work Arrangement-Moderating & & & 0.292 \\
$R^{2}$ & 0.196 & $0.246 \mathrm{k}$ & 0.248 \\
$\Delta R^{2}$ & & $0.050 \mathrm{k}$ & 0.002 \\
$F$-value & $14.653^{*}$ & $9.608^{*}$ & $6.362^{*}$ \\
Note: ${ }^{*}<0.05$ & & & \\
\hline
\end{tabular}

Meanwhile on Table 4, Model 1 shows that work-family conflict also positively influences turnover intention on female employees. Model 2 shows that flexible work arrangements do not significantly influence turnover intention $(\beta=0.138 ; p>0.05)$ but Model 3 shows that moderating effect of flexible work arrangement on the effect of work-family conflict to turnover intention indicates a significant effect $(\beta=-0.976 ; p<0.05)$. In conclusion, hypothesis 3 is supported.

Table 4. Hypotheses testing using flexible work arrangement as the moderating variable and turnover intention as the dependent variable on female employees

\begin{tabular}{lccc}
\hline Variable & Model 1 & Model 2 & Model 3 \\
\hline Work-Family Conflict & $0.513^{*}$ & $0.462^{*}$ & $0.967^{*}$ \\
Flexible Work Arrangement & & 0.138 & $0.789^{*}$ \\
Flexible Work Arrangement-Moderating & & & $-0.976^{*}$ \\
$R^{2}$ & 0.264 & $0.280 \mathrm{k}$ & 0.305 \\
$\Delta R^{2}$ & & $0.016 \mathrm{k}$ & 0.025 \\
$F-$ value & $36.874^{*}$ & $19.823^{*}$ & $14.781^{*}$ \\
Note: ${ }^{*}<0.05$ & & & \\
\hline
\end{tabular}

\section{Discussion}

The hypothesis test results show that hypothesis 1 is supported. Work-family conflict positively influence turnover intention. The higher level of work-family conflict experienced by employee, the chance to quit job is also higher (Mansour \& Tremblay, 2016; Porter \& Ayman, 2013; Wang, et al., 2017)). Confirming the study of Blomme et al., (2010a), this research also indicated that employees who are emotionally exhausted as a result of experience in the work domain encroaching on the family domain showed a higher intention to leave. Work demands that are interfering with employee's responsibilities to fulfill family demands may trigger work-family conflict which in turn impacting the intention to leave his or her workplace.

Staines and Pleck (1983) argued that long working hours give significant impact to employee performance's effectiveness, the quality of marital interaction, and parent-child relationship. In addition to long working hours, holding multiple job or task within a time can trigger interruption or 
disturbance to work-life balance. Furthermore, higher pressures and demands of work that need to be done quickly; lack of energy and time to do all the works; and task or work that has to be done in the same time can result in overworking as of negative emotions may influence job satisfaction (Cleveland et al., 2007).

In the other hand, hypothesis 2 is not supported which means flexible work arrangement do not moderate the effect of work-family conflict on turnover intention. Theoretically, work-life balance policy become an important factor for employees to determine whether possessed resources are suitable with the resources needed. If the needed resources cannot be fulfilled, the possibility for work-family conflict to happen is high and in the end encourage them to quit the job. On the contrary, if hotel management can provide a comfortable and family-friendly work environment, work-family conflict experienced by employees can be minimized therefore employees will stay within organization. But the result is not supporting the above explanation.

This result applied when all male dan female sample were utilized in the analysis. Having different cultural perception over flexible work arrangement may become one of factor why the result is not the same with the previous study. Employees in collectivist country, such as Indonesia, do not mind working longer hours than taking work to home because they prefer to maintain solidarity within the group (Hill et al., 2010). Accordingly, flexible work arrangement offered by organization do not give significant effect to employees. Moreover, the type of hotel can also play a role related to work condition and environment. For example, work condition and environment in chain hotel is better than independent hotel so that facilities offered can help employee to manage their resources (Mansour \& Tremblay, 2016).

In addition, although work-family conflict has positively influence turnover intention on both male and female employees, the moderating effect of flexible work arrangement only happens on female employees. The spillover effect from work to family differs for the two genders (Foley, Yue \& Lui, 2005; Chen, et al., 2018). Occupational stress defined as the transactional process in which stressors, events or properties of event encountered by individuals which will lead to outcomes at both individual and organizational level (Cooper et al., 2001), in this study strongly affected female employees more than male workers. Reacting to this, female employees demand more flexible work arrangements when confronted with negative work experience because the family role identity attached to women than men (Kim \& Gong, 2016). Kim and Gong also stated that flexible work arrangement might help the inter-role transition which makes work-family conflict more flexible. In other words, Brough et al., (2009) stated that reducing work-family conflict will lead to good workfamily balance. Specifically, in the hospitality industry, and especially for female employee, poor work-family balance caused by work-family conflict is a reason to leave the hospitality industry (Walsh \& Taylor, 2007; Blomme, et al., 2013). By offering flexible work arrangements, organizations can decrease the turnover intention rate especially on female employees (Porter \& Ayman, 2013).

In order to maximize the utilization of flexible work arrangement, hotel management need to raise the awareness of flexible work arrangement availability and manager's or supervisor's support on employee's work-life balance is needed (Wang, et al., 2017). Without manager's or supervisor's support, flexible work arrangement utilization by employee will not be effective. In addition, manager's or supervisor's support give positive effect to employee's perception on work (Mansour \& Tremblay, 2016).

While applying flexible work arrangement may reduce the conflict between work and family domain, too much control and choices that employees have can lead to information overload (Allen et al., 2013). Hotel management still have to filter and analyze which type of flexible work arrangement that matches with company's working style and culture. For example, telework will not give much effect on employee who works as a chef or front office because their tasks cannot be brought to home. By identifying and analyzing the right flexible work arrangement, hotel management may reduce employee's work-family conflict and increase employee's intention to stay. 
A managerial implication based on the research that can be inferred is to understand turnover intention as a signal which can lead to an actual turnover. Turnover intention can be avoided by creating and developing comfortable work condition and environment where supervisor and colleagues are supporting each other. By developing a comfortable atmosphere, it is expected that negative emotions triggering work-family conflict will be eliminated so employees do not have any reason to leave the organization anymore. Other family-friendly policies such as building on-site childcare may become one of consideration to management.

Suggestions for future research are: first, the sample used in this study is limited only to employee working in the hospitality industry. It is advised to expand into other industry such as, banking industry, manufacturing industry and hospital so that it can be compared with previous studies which has the same topic. Second, this study only used survey method for data collection. By adding interview method, the data collected may give more insight about the intention to leave in this hospitality industry.

\section{References}

Afsar, B., \& Rehman, Z.U. (2017). Relationship between work-family conflict, job embeddedness, workplace flexibility, and turnover intentions. Makara Hubs-Asia, 21(2), 92-104.

Allen, T.D., Johnson, R.C., Kiburz, K.M., \& Shockley, K.M. (2013). Work-family conflict and flexible work arrangements: deconstructing flexibility. Personnel Psychology, 66, 345-376.

Badan Pusat Statistik. (2017). Statistik mobilitas penduduk dan tenaga kerja 2017. BPS. Retrieved from http://www.bps.go.id/publication/2017/12/25/statistik-mobilitas-penduduk-dan tenaga-kerja-2017.html at $22^{\text {nd }}$ May 2018

Blomme, R.J., Sok, J., \& Tromp, D.M. (2013). The influence of organizational culture on negative work-home interference among highly educated employees in the hospital industry. Journal of Quality Assurance in Hospitality \& Tourism, 14, 1-23.

Blomme, R.J., Van Rheede, A., \& Tromp, D.M. (2010a). The use of the psychological contract to explain turnover intentions in the hospitality industry: a research study on the impact of gender on the turnover intentions of highly educated employees. International Journal of Human Resource Management, 20 (1), 144-162.

Blomme, R.J., Rheede, A.V., \& Tromp, D.M. (2010b). Work-family conflict as a cause for turnover intentions in the hospital industry. Tourism and Hospitality Research, 10, 269 - 285.

Brough, P., O'Driscoll, M., \& Biggs, A. (2009) Parental leave and work-family balance among employed parents following childbirth: an exploratory investigation in Australia and New Zealand. New Zealand Journal of Social Sciences, 4, 71-87.

Bryant, Phil C., and David G. Allen. "Compensation, benefits and employee turnover: HR strategies for retaining top talent." Compensation \& Benefits Review 45.3 (2013): 171-175.

Chen, H., Ayoun, B., \& Eyoun, K. (2018) Work-family conflict and turnover intentions: a study comparing China and U.S. hotel employees, Journal of Human Resources in Hospitality \& Tourism, 17(2), 247-269.

Cleveland, J.N., O’Neill, J.W., Himelright, J.L., Harrison, M.M., Crouter, A.C., \& Drago, R. (2007). Work and family issues in the hospitality industry: perspectives of entrants, managers, and spouses. Journal of Hospitality \& Tourism Research, 31(3), 275-298.

CompData Surveys. (2017). 2016 Turnover Rates by Industry. Retrieved from http://www.compensationforce.com/2017/04/2016-turnover-rates-by industry.html at $15^{\text {th }}$ May 2018 
Cooper, C.L., Dewe, P.J., \& O’Driscoll, M.P. (2001). Organizational Stress: A Review and Critique of Theory, Research, and Applications. London: Sage.

De Sivatte, I.D., \& Guadamillas, F. (2013). Antecedents and outcomes of implementing flexibility policies in organizations. The International Journal of Human Resource Management, 24(7), 1327-1345.

Duxbury, L.E., \& Higgins, C.A. (1991). Gender differences in work-family conflict. Journal of Applied Psychology, 76, 60-74.

Eagly, A. H. (1987). Reporting sex differences. American Psychologist, 42(7), 756-757.

Eagly, A. H., \& Karau, S. J. (1991). Gender and the emergence of leaders: a meta-analysis. Journal of Personality and Social Psychology, 60(5), 685-710.

Foley, S., Hang-Yue, N., \& Lui, S. (2005). The effects of work stressors, perceived organizational support, and gender on work-family conflict in Hong Kong. Asia Pacific Journal of Management, 22(3), 237-256.

Frone, M.R., Yardley, J.L., \& Markel, K.S. (1997). Developing and testing an integrative model of the work-family interface. Journal of Vocational Behavior, 50, 145-167.

Grant, C.A., Wallace, L.M., \& Spurgeon, P.C. (2013). An exploration of the psychological factors affecting remote e-worker's job effectiveness, well-being and work-life balance. Employee Relations, 35(5), 527-546.

Greenhaus, J.H., \& Beutell, N.J. (1985). Sources of conflict between work and family roles. Academy of Management Review, 10, 76-88.

Haar, J.M., Roche, M., \& Taylor, D. (2012). Work-family conflict and turnover intentions of indigenous employees: the importance of the whanau/family for Maori. The International Journal of Human Resources Management, 23(12), 2546-2560.

Hill, E.J., Erickson, J.J., Holmes, E.K., \& Ferris, M. (2010). Workplace flexibility, work hours, and work-life conflict: finding an extra day or two. Journal of Family Psychology, 24(3), 349-358.

Hoque, K. (1999). New approaches to HRM in the UK hotel industry. Human Resource Management Journal, 9(2), 64-76.

Kim, G., \& Gong, Y. (2016). Effects of work-family and family-work conflicts on flexible work arrangements demand: a gender role perspective. The International Journal of Human Resource Management, 28(20), 1-21.

Lambert, A. D., Marler, J. H., \& Gueutal, H. G. (2008). Individual differences: Factors affecting employee utilization of flexible work arrangements. Journal of Vocational Behavior, 73(1), 107-117.

Mansour, S., \& Tremblay, D.G. (2016). Work-family conflict/family-work conflict, job stress, burnout and intention to leave in the hotel industry in Quebec (Canada): moderating role of need for family friendly practices as resource passageways. The International Journal of Human Resource Management, 29(16), 1-33.

Masuda, A.D., Poelmans, S.A.Y., Allen, T.D., Spector, P.E., Lapierre, L.M., Cooper, C.L., Abarca, N., Brough, P., Ferreiro P., \& Fraile, G. (2012). Flexible work arrangements availability and their relationship with work-to-family conflict, job satisfaction, and turnover intentions: a comparison of three country clusters. Applied Psychology, 61(1), 1-29.

McNall, L.A., Masuda, A.D., \& Nicklin, J.M. (2010). Flexible work arrangements, job satisfaction, and turnover intentions: the mediating role of work-to-family enrichment. The Journal of Psychology, 144(1), 61-81. 
Mobley, W.H., Horner S.O., \& Hollingsworth A.T. (1978). An evaluation of precursors of hospital employee turnover. Journal of Applies Psychology, 63, 408-414.

Mortazavi, S., Pedhiwala, N., Shafiro, M., \& Hammer, L. (2009). Work-family conflict related to culture and gender. Community, Work \& Family, 12(2), 251-273.

Netemeyer, R.G., Boles, J.S., \& McMurrian, R. (1996). Development and validation of work-family conflict and family-work conflict scales. Journal of Applied Psychology, 81, 400-410.

OECD. (2011). Doing Better for Families. Paris: OECD Publishing.

Porter, S., \& Ayman, R. (2013). Work flexibility as a mediator of the relationship between work-family conflict and intention to quit. Journal of Management \& Organization, 16(3), 411-424.

Purani, K., \& Sahadev, S. (2007). The moderating role of industrial experience in the job satisfaction, intention to leave relationship: an empirical study among salesmen in India. Journal of Business and Industrial Marketing, 23, 475-485.

Resmiatini, E. (2016). Analisis pengaruh pengaturan kerja fleksibel terhadap konflik kerja-ke-keluarga and intensi keluar: supportive work-family culture sebagai pemediasi. Working paper, Sains Manajemen, Universitas Gadjah Mada Yogyakarta.

Sharma, A. (2012). Work-family conflict and job satisfaction: moderating effects of gender and the salience of the family and work roles. Advances in Asian Social Science, 1(1), 151-161.

Staines, G.L. (1980). Spillover versus compensation: a review of the literature on the relationship between work and nonwork. Human Relations, 33, 111-129.

Staines, G.L., \& Pleck, J.H. (1983). The impact of work schedules on the family. Ann Arbor: University of Michigan.

Suprapto, Y.L., Wibowo, A., \& Harsono, H. (2018). Intra-firm causal ambiguity on cross-functional project team's performance: does openness and an integrative capability matter. International Journal of Managing Projects in Business, 11(4), 901-912.

Swanberg, J. E., James, J. B., Werner, M., \& McKechnie, S. P. (2008). Workplace flexibility for hourly lower-wage employees: A strategic business practice within one national retail firm. The Psychologist-Manager Journal, 11(1), 5.

Timms, C., Brough, P., O’Driscoll, M., Kalliath, T., Siu, O. L., Sit, C., \& Lo, D., (2015). Flexible work arrangements, work engagement, turnover intentions and psychological health. Asia Pacific Journal of Human Resources, 53, 83-103.

Tromp, D.M., \& Blomme, R.J. (2014). Leadership style and negative work-home interference in the hospitality industry. International Journal of Contemporary Hospitality Management, 26(1), 85-106.

U.S. Department of Labor, Bureau of Labor Statistics. (2016). Job Opening and Labor Turnover. Retrieved from http://www.bls.gov/news.release/pdf/jolts.pdf at April 2016

Walsh, K., \& Taylor, M.S. (2007). Developing in house careers and retaining management talent. What hospitality professionals want from their jobs. Cornell and Restaurant Administration Quarterly, 48(2), 163-182.

Wang, I.A., Lee, B.W., \& Wu, S.T. (2017) The relationships among work-family conflict, turnover intention and organizational citizenship behavior in the hospitality industry of Taiwan. International Journal of Manpower, 38(8), 1130-1142. 